DOI: 10.46340/eppd.2020.7.6.22

Oleksandr Gryshchenko

ORCID ID: https://orcid.org/0000-0002-4734-1561

The State Scientific Research Forensic Center of the Ministry of Internal Affairs of Ukraine

\title{
HISTORICAL GENESIS OF USE \\ OF BALLISTIC REGISTRATION EXPERT SERVICE OF MIA OF UKRAINE IN CRIMINAL OFFENSES INVESTIGATION
}

\author{
Олександр Грищенко \\ Державний науково-дослідний експертно-криміналістичноий центру МВС України
}

\section{ІСТОРИЧНА ГЕНЕЗА ВИКОРИСТАННЯ \\ БАЛІСТИЧНОГО ОБЛІКУ ЕКСПЕРТНОЇ СЛУЖБИ МВС УКРАЇНИ У РОЗСЛІДУВАННІ КРИМІНАЛЬНИХ ПРАВОПОРУШЕНЬ}

\begin{abstract}
Ballistic registration is part of the forensic registration system of the Expert Service of the Mol of Ukraine. Prerequisites for its emergence, formation and development are the invention of firearms and the formation of forensic ballistics, as well as the evolution of criminal registration concept, criminology in general and expert institutions involved in the establishment and maintenance of such processes. This article summarizes the historical aspects of ballistic registration establishment under Expert Service of the Mol of Ukraine in its modern state, as well as institutions that were engaged in this activity within different historical periods.

The study used general and specific methods which are a means of scientific research. In particular, comparative method is used during the analysis of substantive and procedural law, scientific categories, definitions and approaches; historical method provided an opportunity to reveal the meaning of "ballistics" and "registration" concepts, to highlight the development of scientific views concerning certain issues; systemic-structural method is used for a comprehensive generalization of the acquired practical experience of ballistic objects registration.
\end{abstract}

Keywords: ballistics, registration, forensic science, expert service, weapon.

Вступ. Оскільки балістичний облік входить до системи криміналістичних обліків Експертної служби МВС України, то передумовами їх виникнення, становлення та розвитку є винахід вогнепальної зброї та формування судової балістики, а також започаткування, становлення та розвиток кримінальної реєстрації, криміналістики в цілому та експертних установ, котрі займались формуванням та веденням таких обліків. Тому, вважаємо необхідними в рамках цієї статті стисло викласти етапи виникнення та становлення криміналістики в цілому, судової балістики та криміналістичної реєстрації, що мали основоположне значення для появи балістичного обліку Експертної служби МВС України у його сучасному вигляді, а також установ, що у різні історичні періоди займались їх веденням.

Стан дослідження. Фундаментальні засади криміналістичної техніки та функціонування криміналістичних обліків розкриті у працях провідних вчених-криміналістів: Г.Л. Грановського, В.В. Бірюкова, А. В. Іщенка, В. С. Митричева, В. І. Пашко, В. Ю. Шепітька.

Однак, балістичні обліки, й зокрема - балістичний облік Експертної служби МВС України не був предметом окремого дослідження. Загальновідомо, щоб з'ясувати сутність явища, слід вивчити його історію. Даний аспект є також недослідженим у науковій літературі.

Мета дослідження. Метою статті є формування історичної генези використання балістичного обліку Експертної служби МВС України у розслідуванні кримінальних правопорушень. 
У дослідженні використовувалися загальнонаукові та спеціальні методи, які є засобами наукового пошуку. Зокрема, спеціально-правові методи: порівняльно-правовий - під час аналізу норм матеріального і процесуального права, наукових категорій, визначень та підходів; історикоправовий - надав можливість розкрити зміст понять «балістика», «облік», висвітлити розвиток наукових поглядів на окремі проблемні питання; системно-структурний метод - для комплексного узагальнення набутого практичного досвіду щодо використання балістичного обліку Експертної служби МВС України у розслідуванні кримінальних правопорушень.

Виклад основного матеріалу. Формування криміналістики та окремих ії розділів здійснювалось багато в чому шляхом використання знань із інших галузей науки та практики. Можна сказати, що завдяки дії закону активного творчого пристосування досягнень різноманітних наук для цілей кримінального судочинства, знання іiї галузі балістики були сприйняті криміналістикою та адаптовані до цілей розкриття, розслідування та попередження кримінальних правопорушень. Слід сказати, що сам термін «судова балістика» почав використовуватися в криміналістичній науці та практиці відносно недавно. У 1937 році відомий судовий медик та криміналіст В.Ф. Черваков після багаторічної роботи щодо узагальнення теорії та практики використання результатів дослідження зброї, боєприпасів, слідів пострілу для вирішення задач судочинства завершив оформлення системи знань у цій галузі та обгрунтував необхідність і доцільність виділення окремого розділу в криміналістиці, який назвав «Судова балістика». Загальноприйнятим вважається, що історія використання вогнепальної зброї бере свій початок із 14 століття. Однак є свідчення про більш давні часи застосування вогнепальної зброї, адже власне поява вогнепальної зброї пов'язана з винаходом пороху.

Вивчення літератури дозволяє говорити про те, що раніше інших фахівців на сліди пострілу звернули увагу медики. Взагалі виникнення науки судової медицини, як правило, відносять до часу узаконення звичаю залучати судових медиків до розв'язання питань розслідування злочинів проти здоров'я та життя громадян.

Першою спробою наукового обгрунтування експертної практики дослідження вогнепальної зброї був вихід у 1874 році в Москві роботи А. Наке «Судебная химия», де значна увага приділялась дослідженню зброї та боєприпасів, встановленню давності стрільби та іншим питанням. В 1879 році в Москві вийшла в світ друга книга, що висвітлювала питання судової балістики, написана медиком М. Щегловим робота «Материал к судебно-медицинскому исследованию огнестрельных повреждений» ${ }^{1}$.

Можливості використання знань з балістики у розкритті та розслідуванні злочинів викликали інтерес науковців га працівників правоохоронних органів різних країн. На почату XX століття в Росії, як і у всьому світі, приділялась досить значна увага вогнепальній зброї як засобу вчинення злочину. Так, в роботі I.M. Снєгірьова «О сыске», що вийшла в 1908 році, значна увага приділяється конструкції основних видів вогнепальної зброї та слідам іiї дії на перешкодах. Професор Лозанського університету Р.А. Рейс, під час лекцій членам делегації судового відомства Росії в 1911 році, приділяє досить значну увагу вогнепальній зброї. В Санкт-Петербурзькому та Одеському кабінетах науковосудової експертизи протягом 1913 року проводять по 1 ідентифікаційній балістичній експертизі, об'єктами яких є кулі та гільзи. У 1915 році, в Харкові виходить книга відомого згодом криміналіста М.С. Бокаріуса «Судебная медицина в изложении для юристов», де, окрім інших питань, висвітлювались і деякі проблеми балістики. В тому ж році у Петербурзі виходить друком фундаментальна робота С.М. Трегубова «Основи уголовной техники. Научно-технические приемы расследования преступлений». В роботі, що складалась з 16 глав докладно описувався процес огляду місця події та слідів, котрі можуть бути там виявлені і вилучені, а також вперше, як нам відомо, докладно висвітлені можливості ідентифікації зброї за слідами на кулях та гільзах ${ }^{2}$.

В грудні 1913 року у французькому журналі «Архіви кримінальної антропології та судової медицини» професор судової медицини із Парижа Балтазар надрукував статтю, в якій стверджував що на денці гільз залишаються характерні сліди ударника, патронного упору (всіх його швів та нерівностей) та зачепу викидача, котрі різні у різних типів зброї․ Так було вперше встановлено, що сліди зброї на стріляній гільзі мають ідентифікаційне значення.

Крім проведення досліджень, на початку XX століття науковці спрямовували свої зусилля на технічне інструментальне та методичне забезпечення балістичних досліджень. Так, керівник

\footnotetext{
${ }^{1}$ Крылов, И.Ф (1980). В мире криминалистики. Ленинград, 129-130.

2 Белкин, Р. С. (1999). История отечественной криминалистики. Москва, 114.

3 Торвальд Ю. (1984). Век криминалистики. Москва, 113.
} 
Московського кабінету науково-судової експертизи В.Л. Русецький у 1916 році розробив прилад для дослідження внутрішньої поверхні ствола вогнепальної зброї і фотографування його особливостей без порушення цілісності конструкції зброї, котрий не був виготовлений у зв'язку з війною та революцією. У 1918 році, професор судової медицини Київською університету К.Л. Таранухін сконструював прилад для макро- та мікрофотографування куль ${ }^{1}$.

Наукові розробки з проблем судової балістики значно пожвавішали після закінчення Першої світової війни. У судово-медичні інститути при університетах, у судово-хімічні лабораторії повернулися піонери судової балістики довоєнного часу, щоб разом з новим поповненням вчених і техніків продовжити перервану війною роботу.

Так, в 1919 р. у Люксембурзі Пьер Мединже знову взявся за вивчення слідів на патронних гільзах. Доктор Г. де Реште (у 1920 році очолив новостворену бельгійську Школу кримінології і поліцейської науки) і підполковник Маже (професор бельгійської військової школи) рік за роком працювали, знімаючи зліпки і відбитки з гільз, фотографуючи їх під мікроскопом, позолочуючи свинцеві кулі, щоб вони краще виходили на фотознімках. Саме завдяки їм європейські установи по ідентифікації вогнепальної зброї довгий час займалися гільзами в набагато більшому обсязі, ніж американські.

У Парижі повернувся до своєї роботи професор Балтазар. Інший французький дослідник Е. Локар з Ліона - йшов власним шляхом. У Голландії доповіді про свої досліди робили такі криміналісти і хіміки, як Гульст і Ван Ледден Гульзебош. В Афінах ставив експерименти грецький дослідник Георгіадіс. Росіяни Матвєєв і Зюськін, як і поляк Соболевський, виступили 3 низкою наукових праць по експертизі вогнепальної зброї. У Німеччині займалися науковими винаходами й експериментами Август Брюнінг і доктор Крафт із Берліна, Фрідріх Петрускі з інституту судової медицини університету в Бреслау, радник поліції Вайценеггер з управління поліції Штутгарта, а також Отто Мецгер, директор бюро хімічних експертиз міста Штутгарта ${ }^{2}$.

Перша у світі спеціалізована експертна установа 3 проблем судової балістики - «Бюро судової балістики» була створена у Нью-Йорку (США) в 1923-1924 роках, а у 1925 році був створений перший порівняльний мікроскоп ${ }^{3}$.

Розвиток судової балістики продовжувався і в Європі.

У СРСР у 1924 році виходить робота І.М. Якимова «Практическое руководство к расследованию преступлений», в третьому розділі якої (Технические методы обнаружения и закрепления следов преступлений) значна увага приділяється методам виявлення, вилучення та дослідження слідів пострілу, а також рекомендації по їх зберіганню ${ }^{4}$.

Вагоме практичне значення для спеціалістів мала робота «Краткое пособие для экспертов», видана ВКР ГУ Робітничо-селянської міліції НКВС СРСР у 1935 році. В Україні відомий вченийкриміналіст С.М. Матвєєв, в 1936 році запропонував копіювати сліди на поверхні кулі за допомогою желатинового покриття фотопластинок, а у 1937 році співробітник Харківського НДІ А.Ф. Дмитрієв створює модель більш досконалого, ніж прилад Брюнінга, апарату для фотографування куль ${ }^{5}$.

Перший в СРСР підручник з криміналістики, випущений в 1935 році (В.I. Громов, C.М. Потапов, I.М. Якімов та ін.) в главі «Уголовная техника», написаній І.М. Якімовим, включав підрозділ «Исследование вещественных доказательств и следов», де досить докладно описані види слідів дії вогнепальної зброї та методів їх виявлення і дослідження. В наступному (другому) підручнику, випущеному в 1938 році, в главу «Исследование вещественных доказательств и следов», також написану I.M. Якімовим, було включено самостійний підрозділ «Экспертиза огнестрельного оружия и огнестрельных повреждений», написаний В.Ф. Черваковим.

Наукові винаходи вчених у різних галузях науки і техніки та їх активне пристосування для потреб дослідження зброї та слідів ії застосування стали основою формування нової галузі криміналістики. В 1937 році, відомий судовий медик та криміналіст В.Ф. Черваков в своїй практичній діяльності проаналізував роботи вчених та практиків світу у галузі дослідження зброї в інтересах судочинства, систематизував їх та визначив систему цих знань як «судова балістика» ${ }^{6}$

\footnotetext{
${ }^{1}$ Крылов И. Ф. (1975). Очерки истории криминалистики и криминалистической экспертизы. Ленинград, 139.

2 Торвальд Ю. (1984). Век криминалистики. Москва, 478-479.

3 Торвальд Ю. (1984). Век криминалистики. Москва, 446-457.

${ }^{4}$ Белкин, Р. С. (1999). История отечественной криминалистики. Москва, 211.

${ }^{5}$ Крылов, И. Ф. (1975). Очерки истории криминалистики и криминалистической экспертизы. Ленинград, 73.

6 Черваков, В. Ф. (1937). Судебная баллистика. Москва.
} 
У 1940 році, в Москві, за співавторством Б.М. Шавера та А.І. Вінберга було видано четвертий підручник: «Криміналістика. Підручник для юридичних шкіл та курсів». Основною відмінністю цього підручника від попередніх було теоретичне обгрунтування поняття науки криміналістики, іiї завдання та предмету, а глава «Уголовная техника» по своєму змісту була подібною до підручників попередніх випусків. Це ж саме можна сказати і про підручники випуску 1945, 1949 та 1950 років.

Першою в СРСР фундаментальною працею в галузі балістики стала колективна робота «Материальная часть стрелкового оружия», видана в двох книгах 1945 та 1946 роках під загальною редакцією академіка Благонравова. В даній роботі було проаналізовано будову різних систем зброї та докладно описано конструктивно-розмірні характеристики найбільш відомих на той час моделей зброї виробництва СРСР та зарубіжних країн.

Однак, науковою основою ідентифікації в сучасній судовій балістиці стали роботи Б.М. Комаринця «Криминалистическрое отождествление огнестрельного оружия по стреляным гильзам» (1955 року) та «Идентификация огнестрельного оружия по выстреленным пулям» (1961 року), а також робота С.Д. Кустановича «Судебная баллистика» (1956 року).

Значний внесок в розвиток судовобалістичної експертизи зробили такі видатні вчені як В.С. Бергер, Г.Л. Грановский, І.А. Дворянский, Б.Н. Срмоленко, В.С. Митричев, М.В. Портнов, С.І. Сташенко, Х.М. Тахо-Годі, С.М. Тихонов, А.І. Устінов, В.В. Філліпов, Б.І. Шевченко та ін.

Окрему увагу слід звернути на розвиток криміналістичних установ СРСР та України.

У 1917 році в СРСР почали створюватись правоохоронні органи, до складу яких було включено створені раніше експертні установи.

В 1919 році колегія НКВС приймає рішення про створення при Центррозшуку кабінету судових експертиз, реєстраційного та дактилоскопічного бюро і Кримінального музею. У м. Харкові, при ВКР НКВС УРСР були створені науково-технічне відділення та фотохімічна частина ${ }^{1}$

В 1923 році затверджено Положення про кабінети судових експертиз, створено Харківський кабінет науково-судової експертизи (керівник Н.С. Бокаріус), Київський (В.І. Фаворський) та Одеський (М.П. Макаренко) кабінети отримали статус державних, а з 1925 року стають інститутами та залишаються єдиними інститутами в СРСР до 1929 року. В РРФСР кабінетів науково-судової експертизи не існувало, однак функціонувала ціла низка НТВ міліції, а окремі балістичні експертизи проводилися в лабораторіях вищих учбових закладів. В вересні 1923 року при Головному управлінні міліції створюється науково-технічний кабінет (завідувач А.А. Єлісєєв, консультант Н.С. Бокаріус) ${ }^{2}$.

У 1944 році при МЮ СРСР була створена Центральна криміналістична лабораторія (керівник Б.І. Шевченко), котра з 1946 року була включена в структуру Всесоюзного інституту юридичних наук МЮ СРСР, з 1 жовтня 1962 року, об’єднавшись з московською лабораторією судових експертиз, перетворена на Центральний НДІСЕ при юридичній комісії Ради міністрів РРФР, котрий в 1970 році перейменовано на Всесоюзний НДІСЕ МЮ СРСР.

В 1949 році у складі НТВ ГУМ організовано Науково-дослідний інститут криміналістики (керівник Б.М. Комаринець), який з 1950 року став вищою загальносоюзною ланкою науковотехнічних підрозділів міліції. Також, в 1949 році було утворено Всесоюзний науково-дослідний інститут криміналістики Прокуратури СРСР (перший керівник С.П. Мітрічев) ${ }^{3}$.

27 грудня 1950 року Міністр юстиції СРСР затвердив Положення про експертну установу. Таким чином, в 1950-ті роки в СРСР функціонувало три загальносоюзні експертні установи, що підпорядковувались різним правоохоронним відомствам.

Науково-технічна служба НКВС СРСР була виділена в самостійну службу лише на початку 1950-х років. У його структурі вперше з'явилась окрема балістична лабораторія.

Перша настанова з питань регламентації діяльності криміналістичних підрозділів органів внутрішніх справ була затверджена наказом МВС СРСР від 10 лютого 1972 року № 45. Наказом МВС СРСР від 30 листопада 1989 року № 300 «Про підвищення ефективності діяльності експертнокриміналістичних підрозділів органів внутрішніх справ» було удосконалено окремі положення діючої Настанови. Цим ще наказом НТВ були перейменовані в експертно-криміналістичні управління (відділи, відділення, групи).

\footnotetext{
${ }^{1}$ Белкин, Р. С. Винберг, А. И. (1982). История советской криминалистики: Этапь возникновения и становления науки (1917-1930-е). Москва, 65.

2 Белкин, Р. С. (1999). История отечественной криминалистики. Москва, 116.

${ }^{3}$ Белкин, Р. С. Винберг, А. И. (1982) История советской криминалистики: Этапь возникновения и становления науки (1917-1930-е.). Москва, 69-76.
} 
Наказом МВС Української РСР від 31 травня 1991 року № 212/дск «Про затвердження Положення про Експертно-криміналістичне управління МВС УРСР, Приблизного положення про експертно-криміналістичний відділ, відділення обласних УВС, УВСТ» було суттєво збільшено організаційно-штатну чисельність експертно-криміналістичних підрозділів ОВС УРСР, а також розширено повноваження ЕКУ МВС УРСР як вищої керівної ланки експертної служби ОВС.

Після розпаду СРСР та проголошення незалежності України виникла необхідність створення центрального експертного підрозділу, котрий забезпечував би розробку методик проведення досліджень, виконання найбільш складних та повторних експертиз, а також ведення центральних криміналістичних обліків. Такий підрозділ було створено наказом МВС України № 59 від 10 лютого 1992 року «Про створення криміналістичного центру при МВС України».

Діяльність експертно-криміналістичних підрозділів ОВС в умовах незалежної України було вперше регламентовано наказом МВС України від 9 березня 1992 року № 140 «Про затвердження Положення про діяльність експертно-криміналістичних підрозділів органів внутрішніх справ України». Наказом МВС України від 14 січня 1994 року № 190 «Про введення Інструкції по формуванню, веденню та використанню криміналістичних обліків Криміналістичного центру Міністерства внутрішніх справ України» було започатковано ведення центральних криміналістичних обліків в ОВС України.

Постановою Кабінету Міністрів України від 6 травня 1998 року № 617, було утворено Державний науково-дослідний експертно-криміналістичний центр МВС України.

Настанова про діяльність експертно-криміналістичної служби МВС України була затверджена наказом МВС України від 30 серпня 1999 року № 682, стала одним з основних відомчих нормативноправових актів, що регламентує діяльність служби в сучасних умовах. Постановою Кабінету Міністрів України від 20 червня 2000 року № 988 було утворено Експертну службу МВС України, котра на сьогоднішній день охоплює експертні підрозділи МВС України всі рівнів.

Як свідчать літературні джерела, першими серед усіх існуючих на сьогоднішній день балістичних обліків було запроваджено оперативно-довідкові обліки, а саме: облік зброї, що застосовувалась під час вчинення злочинів, та зброї, вилученої із незаконного обігу. Поява першого 3 них стала можливою завдяки виникненню та розвитку в країнах західної Європи правової статистики. Однак, існуючі на початку XIX ст. у Франції обліки накопичували лише статистичні дані, що відображали кількість зброї, що застосовувалась при вчинені вбивств та назви місцевостей, де були вчинені вбивства ${ }^{1}$.

Поява обліку вогнепальної зброї, вилученої із незаконного обігу, перш за все була пов'язана із запровадженням у окремих державах обмежень щодо прав володіння зброєю їх громадянами та проведенням правоохоронними органами цих держава заходів по вилученню зброї із незаконного обігу. Так, лише у Нью-Йорку (США), протягом 1922 року поліцією було вилучено із незаконного обігу більше 3 тисяч одиниць ручної вогнепальної зброї르.

Першими довідково-інформаційними балістичними обліками, створеними для потреб боротьби зі злочинністю, були колекції вогнепальної зброї та довідники з описаннями та зображеннями іiі основних конструктивно-розмірних та технічних характеристик.

Перші історичні відомості про запровадження експертно-криміналістичного обліку куль та гільз, вилучених з місць нерозкритих злочинів відносяться до початку XX ст.

Проаналізувавши низку літературних джерел, можна зробити обережний висновок про те, що на почату XX століття в Росії, незважаючи на досить значні успіхи багатьох вчених і практиків в галузі балістичних досліджень, жодних криміналістичних балістичних обліків загальнодержавного або регіонального масштабів не існувало. Окремі відомості про тяжкі злочини, вчинені із використанням вогнепальної зброї, знаходили своє відображення у формах статистичної звітності, однак інформація про зброю у картках різних форм звітності носила факультативних характер, тому в більшості випадків не фіксувалась.

Перший оперативно-довідковий криміналістичних балістичний облік в УРСР був запроваджений наказом народного комісара республіки України від 14 квітня 1936 року № 80 «Про введення Інструкції по обліку зброї, що вилучається органами міліції у населення».

\footnotetext{
${ }^{1}$ Остроумов, С .С. (1962). Советская судебная статистика. Часть общая и специальная. Москва, 332.

2 Торвальд, Ю. (1984). Век криминалистики. Москва, 461.
} 
Виходячи із вищезазначеного, в перші десятиліття існування СРСР, існуючі криміналістичні обліки, у тому числі балістичні, будь яких суттєвих змін не зазнавали, а нові види обліків з'являлися лише на регіональному рівні і виключно у порядку власної ініціативи працівників низових підрозділів ${ }^{1}$.

Започаткування в СРСР криміналістичних балістичних обліків тісно пов'язано $з$ діяльністю Б.М. Комаринця, котрий в 1940 році очолив НТВ ГІМ НКВС СРСР, а з 1949 року НДІ криміналістики у складі НТВ ГУМ НКВС СРСР. Б.М. Комаринець займався розробкою широкого спектру питань в галузі криміналістики, однак, на нашу думку, його роботи в галузі ідентифікації в судовій балістиці стали найбільш вагомим внеском в розвиток криміналістичної науки.

Першим методичним посібником з питань функціонування криміналістичних балістичних обліків стала робота «Використання кулегільзотек при розслідуванні злочинів», видана в 1963 році. Автори цього посібника (В.П. Власов, А.Н. Самончик) досить докладно виклали методичні рекомендації щодо організації кулегільзотек, правила направлення матеріалів в кулегільзотеки, а також принципи роботи кулегільзотек. Також в роботі містяться рекомендації щодо направлення в Центральну картотеку куль та гільз крім карток із описаннями та зображеннями куль та гільз, самих куль та гільз зі слідами зброї, вилученим по найбільш резонансним злочинам, або якщо є підозра, що злочин вчинено «злочинцями-гастролерами». Решта об’єктів в натурному вигляді повинна зберігатись в кущових кулегільзотеках.

Нормативно-правове закріплення функціонування кулегільзотек на центральному та регіональному рівнях було здійснено в першій Настанові по роботі криміналістичних підрозділів органів внутрішніх справ, затвердженій наказом МВС СРСР від 10 лютого 1972 року № 45.

Створення державної кулегільзотеки всієї зброї, що перебуває в обігу на території України, вперше було започатковано наказом МВС України від 25 березня 1993 року № 164 «Про затвердження Інструкції про порядок виготовлення, придбання, зберігання, обліку, перевезення і використання вогнепальної зброї, боєприпасів до неї та вибухових матеріалів».

Ведення центрального криміналістичного обліку куль, гільз та патронів зі слідами зброї, вилучених по фактам вчинення злочинів на території України, в центральному експертному підрозділі МВС України стало можливим лише після створення Центру криміналістичних досліджень (наказ МВС України № 59 від 10 лютого 1992 року) та розбудови його матеріально-технічної бази.

Наказом МВС України від 30 серпня 1998 року було затверджено Настанову про діяльність експертно-криміналістичної служби МВС України, котра на сьогоднішній день $є$ основним нормативно-правовим актом з питань регламентації функціонування криміналістичних обліків (розділ 6 Настанови). Функціонування обліку куль і гільз зі слідами зброї регламентовано п. 6.6. Настанови.

3 метою удосконалення нормативно-правової бази функціонування балістичних обліків та конкретизації окремих положень наказу № 682-98 р. було прийнято наказ МВС України від 2 вересня 1998 року, котрим було затверджено Інструкцію про створення в системі МВС України кулегільзотеки табельної, відомчої, мисливської і спортивної нарізної вогнепальної зброї та Інструкцію про формування, ведення і використання криміналістичного обліку гільз із слідами гладкоствольної вогнепальної зброї.

Висновки. Балістичні обліки в сучасній теорії криміналістики, на підставі причетності їх до події злочину диференціюються на оперативно-довідкові, експертно-криміналістичні та довідково-інформаційні (довідково-допоміжні); по способу накопичення реєстраційної інформації - на картотеки, колекції, альбоми, комп'ютерні бази даних тощо, а також змішані. Для запровадження кожного з видів балістичних обліків повинні виникнути певні передумови, якими, на нашу думку, являється рівень розвитку криміналістичних знань на певному історичному відрізку в галузі дослідження зброї та криміналістичної реєстрації. Тому природно, що кожен із сучасних видів балістичних обліків впроваджувався в різні історичні періоди і в різних місцевостях, а до досягнення сучасного рівня свого функціонування підлягав численним видозмінам та удосконаленням, викликаним потребами практики боротьби зі злочинністю та новими досягненнями криміналістичної науки.

\footnotetext{
${ }^{1}$ Пашко, В. І. (1995). Наукові та методичні основи організації і використання експертно-криміналістичних обліків органів внутрішніх справ України: автореферат дисертації на здобуття наукового ступеня кандидата юридичних наук. Київ.
} 


\section{References:}

1. Krylov, I. F. (1980). V mire kriminalistiki [In the world of forensic science]. Leningrad: LGU [in Russian].

2. Belki, R. S. (1999). Istoriia otechestvennoy kriminalistiki [History of Russian forensics]. Moscow: NORMA [in Russian].

3. Torvald, Iu. (1984). Vek kriminalistiki [The Age of Forensics]. Moscow: Progress [in Russian].

4. Krylov, I. F. (1975). Ocherki istorii kriminalistiki i kriminalisticheskoy ekspertizy [Essays on the history of forensic science and forensic expertise]. Leningrad: LU. [in Russian].

5. Chervakov, V. F. (1937). Sudebnaia ballistika [Forensic ballistics]. Moscow: Narkomiust SSSR [in Russian].

6. Belkin, R.S., Vinberg, A.I. (1982). Istoriia sovetskoy kriminalistiki: etapy vozniknoveniia i stanovleniia nauki (1917-1930 g.) [History of Soviet criminalistics: Stages of the emergence and formation of science (1917-1930)]. Moscow: AMVD SSSR. [in Russian].

7. Ostroumov, S. S. (1962). Sovetskaia sudebnaia statistika: chast obshchaia i spetsialnaia [Soviet judicial statistics: general and special part]. Moscow: Mosk. un-t [in Russian].

8. Pashko, V. I. (1995). Naukovi ta metodychni osnovy orhanizatsii i vykorystannia ekspertno-kryminalistychnykh oblikiv orhaniv vnutrishnikh sprav Ukrainy [Scientific and methodical bases of the organization and use of forensic records of law-enforcement bodies of Ukraine]. Kyiv [in Ukrainian]. 